Article

\title{
Soil Respiration Changes after Prescribed Fires in Spanish Black Pine (Pinus nigra Arn. ssp. salzmannii) Monospecific and Mixed Forest Stands
}

\author{
Pedro Antonio Plaza-Álvarez ${ }^{1, *}$, Manuel Esteban Lucas-Borja ${ }^{1}$ [D , Javier Sagra ${ }^{1}$, \\ Daniel Moya $^{1}{ }^{10}$, Teresa Fontúrbel ${ }^{2}$ and Jorge de las Heras ${ }^{1}$ \\ 1 Escuela Técnica Superior de Ingenieros Agrónomos y de Montes (ETSIAM), Universidad de Castilla-La \\ Mancha, Campus Universitario s/n, 02071 Albacete, Spain; manuelesteban.lucas@uclm.es (M.E.L.-B.); \\ Javier.Sagra@uclm.es (J.S.); daniel.moya@uclm.es (D.M.); Jorge.Heras@uclm.es (J.d.l.H) \\ 2 Centro de Investigación Forestal-Lourizán, Consellería do Medio Rural, Xunta de Galicia, P.O. Box 127, \\ 36080 Pontevedra, Spain; maria.teresa.fonturbel.1literas@xunta.gal \\ * Correspondence: Pedro.Plaza@uclm.es; Tel.: +34-629832732
}

Academic Editors: Xavier Úbeda and Victoria Arcenegui

Received: 25 April 2017; Accepted: 6 July 2017; Published: 13 July 2017

\begin{abstract}
Soil respiration is a major carbon pathway sensitive to environmental changes. Using prescribed burnings to reduce fuel accumulation and lower risks of large-scale wildfires has recently become more important. Prescribed burning can significantly alter the soil environment, but its effect in practice on soil respiration is not sufficiently understood. We evaluated the effects of prescribed burning on soil respiration before and after burning (May-July 2016). Prescribed burning was conducted in two natural pine areas by comparing a mixed stand of Pinus nigra Arn. ssp. salzmannii with Pinus pinaster Ait. to a pure stand of Pinus nigra Arn. ssp. salzmannii in the central Iberian Peninsula. Soil respiration was measured by an EGM-4 (Environmental Gas Monitor) infrared gas analyser in both burned and unburned (control) plots. Burnings were low-intensity, and slightly more energetic in the pure stand given its larger litter volume. Post-burning soil respiration followed a similar evolution to that in the control plots, but was greater in the pure stand burned zone and slightly lower in the burned plots in the mixed stand. No significant differences were found in any stand. Soil respiration significantly changed in temporal evolution due to increasing temperatures when summer began. We conclude that prescribed fire induces no changes in SR immediately after fire. This study helps understand how prescribed burnings can affect soil respiration in pure and mixed Spanish black pine forest stands.
\end{abstract}

Keywords: soil properties; low-intensity fire; forest fires; microbiological soil properties; soil quality; soil $\mathrm{CO}_{2}$ efflux

\section{Introduction}

Fire is a natural disturbance that forms part of Mediterranean ecosystem dynamics [1], yet in the last few decades the number and scale of wildfires have increased in most countries of the Mediterranean Region [2] creating a major challenge to these ecosystems. The leading cause of the increasing size and number of fires is land use changes. However, climate factors have also contributed, particularly, less precipitation and rising temperatures, which are more acute during the driest season when plants display their lowest moisture levels, leading to an accumulated rise in fuel [1,3-5]. As a direct effect of heating, wildfires in terrestrial ecosystems remove and modify vegetation cover. Indirectly, the long-term spatial and temporal changes in soil properties related to the impact of fire potentially altering the ecosystem [6]. 
In this context, forest managers are currently applying prescribed fires as a tool to buffer the impact of wildfires on forest ecosystems properties. Prescribed burning either reduces fuel loading or modifies the fuel structure by constraining the size and severity of forest fires, even under extremely severe weather conditions [7]. Forest services and land managers currently implement prescribed burning as a land management tool to diminish fuel loads in fire-prone landscapes, mainly to minimise the extent and severity of wildfires, or to facilitate the germination and growth of desired forest species [8-11]. However, prescribed burning effects on the forest ecosystem present several negative consequences [12]. Hence, it is extremely important to understand and quantify the potential impact of prescribed burning on soil physico-chemical and microbiological properties. In particular, catchment-scale studies often report minimal impacts of prescribed fires on soil properties, while plot- and hillslope-scale studies frequently detect more substantial impacts [13-16].

Fire influences soil formation as it modifies the nutrients cycle [17], physico-chemical soil properties [18] and microbiological processes [19]. The soil microbiota is constituted by a microscopic mixture of thousands and millions of bacteria, fungi, protozoa, etc. The soil microbiota plays an essential role in the degradation, mineralisation and oxidation-reduction processes of existing matter to maintain soil fertility and functionality.

Different microbiological parameters, such as soil respiration (SR) or soil biomass carbon, and many different extracellular enzyme activities, may be closely related to either the corresponding element cycling (i.e., C, N and P) or the amount of carbon degradation [20]. SR has been widely used as a soil quality indicator to evaluate soil degradation in relation to changes in forest soil [21-24] and agricultural soil $[25,26]$ in many Mediterranean areas. SR, which refers to the $\mathrm{CO}_{2}$ flux from soil to the atmosphere, is the second largest terrestrial source of $\mathrm{CO}_{2}$ and an important part of the global C cycle, and can be 10 times that produced by fossil fuel combustion [27]. Total respiration from soil originates from the activity of root and rhizosphere organisms (autotrophic respiration), and from the microbial decomposition of organic matter (heterotrophic respiration) [28]. Recent research has focused on analysing the effects of disturbances to soil $\mathrm{C}$ contents and $\mathrm{CO}_{2}$ fluxes, such as wildfire or controlled burning [29-31]. Despite the global importance of this process, knowledge about SR variability across ecosystem types, vegetation communities, and responses to natural or human disturbances, is still limited [32,33].

SR provides an important tool for understanding how soil processes are affected by prescribed fires in the Mediterranean Region. This work aims to evaluate the effect of understory prescribed fires on SR in two forest ecosystems: one composed of a monospecific Spanish black pine (Pinus nigra Arn. ssp. salzmannii) forest and the second that comprises Spanish black pine (Pinus nigra Arn. ssp. salzmannii) and maritime pine (Pinus pinaster Ait.). Both are located in the Cuenca Mountains (central Iberian Peninsula). We hypothesised that prescribed fire, due to low-intensity fire in the mixed and the monospecific forest stands, induces no changes in SR immediately after fire.

\section{Materials and Methods}

\subsection{Study Site}

The study area is located in the central Iberian Peninsula, specifically in the Castilla-La Mancha region. The study plots represent the range of typical black pine stands in Spain: a monospecific stand and one mixed with maritime pine. The two locations are situated in the northern part of this region, in the province of Cuenca. One of them is found in the El Pozuelo municipality $\left(40^{\circ} 33^{\prime} 53.5^{\prime \prime} \mathrm{N}\right.$ $\left.2^{\circ} 16^{\prime} 30.4^{\prime \prime} \mathrm{W}\right)$. Altitude ranges from 1000 to $1050 \mathrm{~m}$ a.s.l. The average annual temperature in the area is $11.3^{\circ} \mathrm{C}$ (mean temperatures of the coldest month $=2.7^{\circ} \mathrm{C}$; mean highest temperatures of the hottest month $=23.0^{\circ} \mathrm{C}$ ), with a total annual precipitation of $700 \mathrm{~mm}$, according to the Spanish National Meteorological Agency for the 1950-2016 period). The ground is flat with a mean slope of $5 \%$ and the dominant vegetation for the stand is a mixed forest of $P$. pinaster and P. nigra, hereafter MS. The structure stand characteristics are provided in Table 1. The second location is named Beteta 
$\left(40^{\circ} 33^{\prime} 02.9^{\prime \prime} \mathrm{N} 2^{\circ} 06^{\prime} 32.6^{\prime \prime} \mathrm{W}\right)$, and is relatively close to the previous one (approx. $15 \mathrm{~km}$ ). Altitude ranges from 1250 to $1300 \mathrm{~m}$ a.s.l. The mean annual temperature in the area is $10.2^{\circ} \mathrm{C}$ (mean lowest temperatures of the coldest month $=1.7^{\circ} \mathrm{C}$; mean highest temperatures of the hottest month $=20.1^{\circ} \mathrm{C}$ ), with a total annual precipitation of $946 \mathrm{~mm}$ (Spanish National Meteorological Agency for the 1950-2016 period). The ground is flat ( $\%$ slope) and the stand is formed by a monospecific forest of $P$. nigra. This stand is abbreviated to PS. Other different characteristics are found in Table 1. The $\mathrm{pH}$ of top soil is 7.3 in the pure stand and 6.9 in the mixed stand. The texture is clay in the pure stand and loamy-sand in the mixed stand (Soil Survey Staff USDA [34]).

\subsection{Experimental Design}

In the spring of 2016, six plots of $50 \times 50 \mathrm{~m}$ were randomly set up in the Pozuelo (a P. nigra and P. pinaster mixed forest stand; MS) and Beteta (a monospecific P. nigra forest stand; PS) forests. Three of these six plots were chosen randomly to be burned by a prescribed burning treatment, with the remaining three plots left unburned. Before burning, different forest stand characteristics were surveyed; e.g., plant tree cover, shrubs under trees and slope, density of trees, diameter at breast height and mean stand height (Table 1). Different soil samples were also collected to evaluate the physical soil properties in each plot. Prescribed burning was carried out by the Regional Forest Service of Castilla-La Mancha on 18 May 2016. Burning was performed by manual fire lines, separated $1 \mathrm{~m}$ apart, which were perpendicular and in the opposite direction to the wind direction. Thus, they were the low-intensity burning type. The soil temperature during these burnings was recorded in the litter layer above the mineral soil surface and at a depth of $2 \mathrm{~cm}$ in mineral soil. SR was measured at six permanent points in each plot (total $N=18$ ) by an EGM-4 (Environmental Gas Monitor) infrared gas analyser (IRGA; PP-Systems, Amesbury, MA, USA) connected to a PVC collar that snugly fit over the cores. Soil temperature and moisture were measured permanently before and after burning by digital temperature sensors and VG400 humidity sensors (Vegetronix, Riverton, UT, USA), both connected to a datalogger hobo. Sensors were placed at a depth of $2 \mathrm{~cm}$ (total of 6): three in the control plots and three in the burned plots Measurements were taken: (i) 2 days before the prescribed burning (16 May 2016); (ii) 7 days after burning (25 May 2016); (iii) 1 month after burning (21 June 2016); (iv) 70 days after burning (27 July 2016).

Soil properties were measured 2 days before and 7 days after prescribed burning. Soil organic $\mathrm{C}$ was determined according to the Walkley and Black method [35]. Total $\mathrm{N}$ was analysed by dry combustion in a LECO Elemental Analyzer (LECO, Saint Joseph, MI, USA). Microbial biomass C (Cmic) was determined by the fumigation-extraction method [36] with colorimetric measurements. Cmic contents were calculated by the difference between fumigated and non-fumigated samples, and by applying a KEC factor (efficiency of microbial biomass C extraction) of 2.64 [36].

Table 1. Forest stand characteristics in the study areas. Mean vales and standard deviation. $n$ : Number of plots.

\begin{tabular}{|c|c|c|c|c|c|c|}
\hline Stand & $n$ & Tree Composition & $\begin{array}{l}\text { Tree Density } \\
\text { (No./ha) }\end{array}$ & $\begin{array}{l}\text { Mean Diameter at } \\
\text { Breast Height }(\mathrm{cm})\end{array}$ & $\begin{array}{l}\text { Mean Tree } \\
\text { Height (m) }\end{array}$ & Shrubs Species \\
\hline Pure & 6 & $\begin{array}{c}\text { Pinus nigra Arn. ssp. } \\
\text { salzmannii }\end{array}$ & $1281(256)$ & $20.6(12.7)$ & $7.25(3.27)$ & $\begin{array}{l}\text { Genista scorpius L., Arctostaphylos } \\
\text { uva-ursi L., Juniperus communis L., } \\
\text { Rosa canina L., Amelanchier ovalis } \\
\text { Medik., Lavandula spp., Thymus spp. }\end{array}$ \\
\hline Mixed & 6 & $\begin{array}{l}\text { Pinus nigra Arn. ssp. } \\
\text { salzmannii and Pinus } \\
\quad \text { pinaster Ait. }\end{array}$ & $667(125)$ & $18.7(8.7)$ & $7.49(3.68)$ & $\begin{array}{l}\text { Quercus faginea Lam., Cistus } \\
\text { laurifolius L., Berberis vulgaris L., Rosa } \\
\text { canina L., Prunus spinosa L., Crataegus } \\
\text { monogyna Jacq., Juniperus oxycedrus L. } \\
\text { and. Lavandula spp. }\end{array}$ \\
\hline
\end{tabular}




\subsection{Statistical Analyses}

Data were submitted to a two-way ANOVA, in which prescribed fires and dates, and their interaction were selected as factors. All the plots can be considered spatially independent. The applied post hoc test was Fisher's least significant difference (LSD) method. A significance level of $p<0.05$ was adopted throughout, unless otherwise stated. To satisfy the assumptions of the statistical test (equality of variance and normal distribution), variables were square-root transformed whenever necessary. In addition, the Pearson coefficient correlation was calculated for SR and soil temperature and moisture at each forest stand (mixed and pure forest stand). The software used for the statistical analysis was Statgraphics Plus 15.0 (Statpoint Technologies, Warrenton, VA, USA).

\section{Results}

\subsection{Thermal Regime During Burning}

Prescribed burning was monitored. Burning intensity was very similar in both study areas. There was a difference in the organic layer, which was larger in the pure stand than in the mixed one, and it reached a maximum temperature of $362^{\circ} \mathrm{C}$. The temperatures were comparable in the mineral soil. The duration of temperatures was somewhat longer in the organic layer of the pure stand and reached $18 \mathrm{~s}$, with a temperature higher than $60^{\circ} \mathrm{C}$. The reached temperatures are seen in Table 2 .

Table 2. Maximum temperatures during prescribed fires. Mean values and standard deviations.

\begin{tabular}{cccccc}
\hline Stand & $\begin{array}{c}\text { Organic } \\
\text { Layer }\left({ }^{\circ} \mathbf{C}\right)\end{array}$ & $\begin{array}{c}\text { Mineral Soil } \\
\text { Surface }\left({ }^{\circ} \mathbf{C}\right)\end{array}$ & $\begin{array}{c}\mathbf{2} \text { cm Depth Soil } \\
\text { Surface }\left({ }^{\circ} \mathbf{C}\right)\end{array}$ & $\begin{array}{c}\text { With Temperatures } \\
\text { above } \mathbf{6 0}{ }^{\circ} \mathbf{C}(\mathbf{s})\end{array}$ & $\begin{array}{c}\text { With Temperatures } \\
\text { above } \mathbf{1 0 0}{ }^{\circ} \mathbf{C}(\mathbf{s})\end{array}$ \\
\hline Pure & $361 \pm 29$ & $37 \pm 4$ & $18 \pm 3$ & $18 \pm 5$ & $2 \pm 1$ \\
Mixed & $264 \pm 62$ & $35 \pm 2$ & $21 \pm 2$ & $13 \pm 2$ & $1 \pm 0$ \\
\hline
\end{tabular}

\subsection{Soil Temperature and Soil Moisture Monitoring}

For the soil temperature, we did not find a significant difference between the burned and control zones. The temperatures of the pure and mixed stands, which were evaluated separately, tended to be similar for both treatments, but magnitudes were slightly higher in the burned plots compared to the pure stand, and were higher in the control plots versus the mixed stand (see Figure 1).

The relationship between SR and both humidity and temperature was performed by a Pearson correlation. Moisture and SR correlated with a coefficient of 0.384 and $p=0.0009$ in the pure stand and with one of 0.3462 and $p=0.0029$ in the mixed stand. Soil temperature and SR correlated with a coefficient of 0.309 and $p=0.0083$ in the pure stand and with one of 0.285 and $p=0.0154$ in the mixed stand.
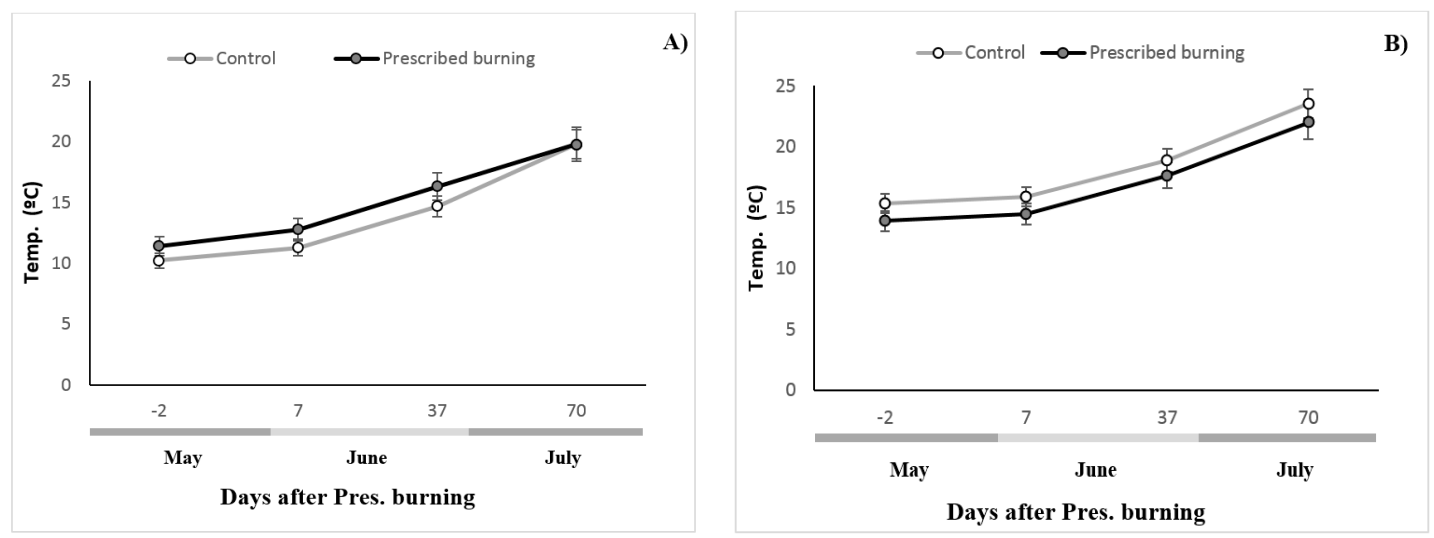

Figure 1. Cont. 


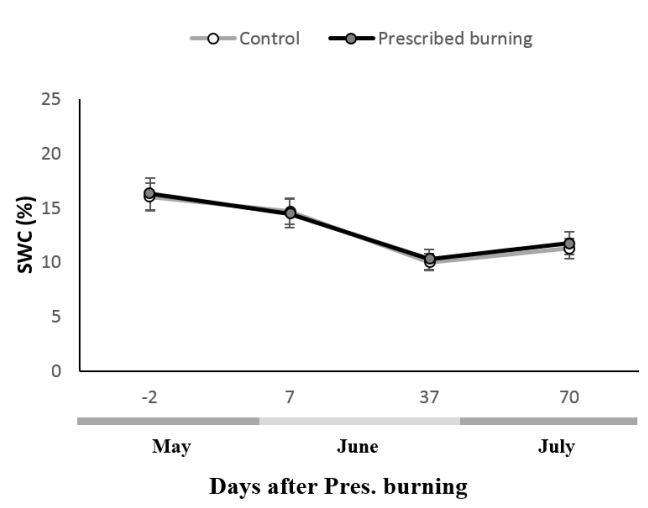

A)

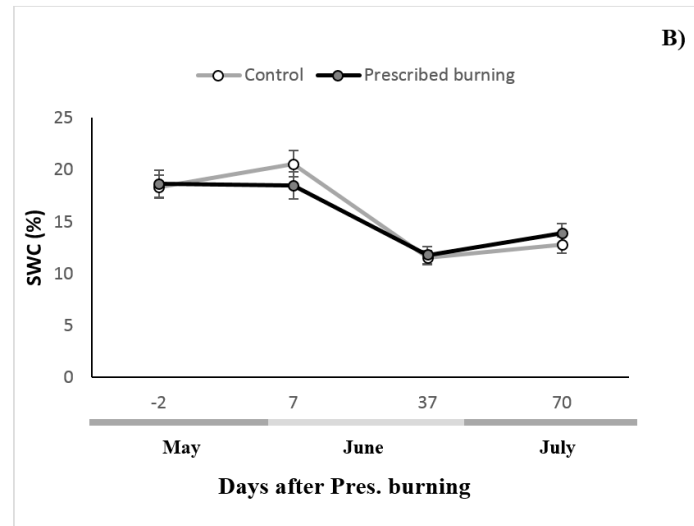

Figure 1. Temporal evolution of the soil temperature $\left({ }^{\circ} \mathrm{C}\right)$ and water soil content $(\mathrm{SWC}, \%)$ (mean \pm Standard Error) in the control and burned zones. (A) corresponds to the pure stand, and (B) to the mixed stand.

\subsection{Soil Properties}

No changes were detected in soil organic $\mathrm{C}$ and $\mathrm{N}$ contents, the $\mathrm{C} / \mathrm{N}$ ratio and microbial biomass $\mathrm{C}$ as a result of prescribed burning in the pure and mixed stands (Table 3 ).

Table 3. Soil characteristics for each site before and after the prescribed fire treatment. Mean values and standard deviations. There were no significant differences $(p<0.05)$ before and after burning for each stand type.

\begin{tabular}{|c|c|c|c|c|c|}
\hline \multicolumn{6}{|c|}{ Pure Stand } \\
\hline Plots & Treatment & $\begin{array}{c}\text { Organic } \\
\text { Carbon (\%) }\end{array}$ & Total N (\%) & $\mathbf{C} / \mathbf{N}$ & $\begin{array}{c}\text { Microbial C } \\
\text { Biomass (mg/kg) }\end{array}$ \\
\hline \multirow{2}{*}{ Control } & Before burning & $8.7 \pm 1.8$ & $0.46 \pm 0.04$ & $19.4 \pm 2.9$ & $1707 \pm 121$ \\
\hline & After burning & $8.3 \pm 0.2$ & $0.47 \pm 0.04$ & $17.7 \pm 0.8$ & $1930 \pm 113$ \\
\hline \multirow{2}{*}{ Burned } & Before burning & $10.4 \pm 2.9$ & $0.52 \pm 0.07$ & $20.2 \pm 3.3$ & $1974 \pm 169$ \\
\hline & After burning & $9.8 \pm 1.3$ & $0.48 \pm 0.03$ & $20.1 \pm 2.1$ & $2168 \pm 69$ \\
\hline \multicolumn{6}{|c|}{ Mixed Stand } \\
\hline Plots & Treatment & $\begin{array}{c}\text { Organic } \\
\text { carbon }(\%)\end{array}$ & Total N (\%) & $\begin{array}{l}\text { Organic } \\
\text { Carbon }\end{array}$ & $\begin{array}{c}\text { Microbial C } \\
\text { biomass (mg/kg) }\end{array}$ \\
\hline \multirow{2}{*}{ Control } & Before burning & $4.3 \pm 0.4$ & $0.14 \pm 0.01$ & $30.8 \pm 0.5$ & $836 \pm 96$ \\
\hline & After burning & $4.7 \pm 0.8$ & $0.15 \pm 0.01$ & $30.6 \pm 2.9$ & $749 \pm 97$ \\
\hline \multirow[b]{2}{*}{ Burned } & Before burning & $5.6 \pm 0.1$ & $0.21 \pm 0.03$ & $29.0 \pm 4.5$ & $953 \pm 248$ \\
\hline & After burning & $4.5 \pm 0.3$ & $0.15 \pm 0.03$ & $32.4 \pm 6.3$ & $1275 \pm 39$ \\
\hline
\end{tabular}

\subsection{Burning and Site Effect on Soil Respiration after Prescribed Fires}

In both the pure stand and mixed stands, no significant differences in SR $(p<0.05)$ were observed between the burned and control plots at any time during the study. However, significant differences in SR were found in both the pure and mixed stands on the different sampling dates, which proved to be a significant increase as summer progressed (Table 4 and Figure 2).

In the mixed stand, no significant correlations were found among $S R$ and organic $C, N, C / N$ and microbial biomass $C$ ( $r$ ranging from 0.15 to $0.54 ; p>0.05$ ). In the pure stand, SR correlated positively and significantly with soil organic $\mathrm{C}(r=0.70 ; p=0.01)$ and $\mathrm{C} / \mathrm{N}(r=0.61 ; p=0.03)$, but was not significantly correlated with total $\mathrm{N}$ and microbial biomass carbon $(r=0.25$ and $r=0.10$; respectively). 
Table 4. Result of two-factor ANOVA (site and prescribed fire) for soil $\mathrm{CO}_{2}$ efflux.

\begin{tabular}{ccccc}
\hline & \multicolumn{2}{c}{ Beteta (Pure Stand) } & \multicolumn{2}{c}{ Pozuelo (Mixed Stand) } \\
\hline Factors & F-Ratio & $\boldsymbol{p}$-Value & F-Ratio & $\boldsymbol{p}$-Value \\
Date & 3.94 & 0.0121 & 3.96 & 0.0118 \\
Fire & 4.32 & 0.0518 & 2.02 & 0.1604 \\
Date $x$ Fire & 0.38 & 0.7677 & 0.20 & 0.8966 \\
\hline
\end{tabular}
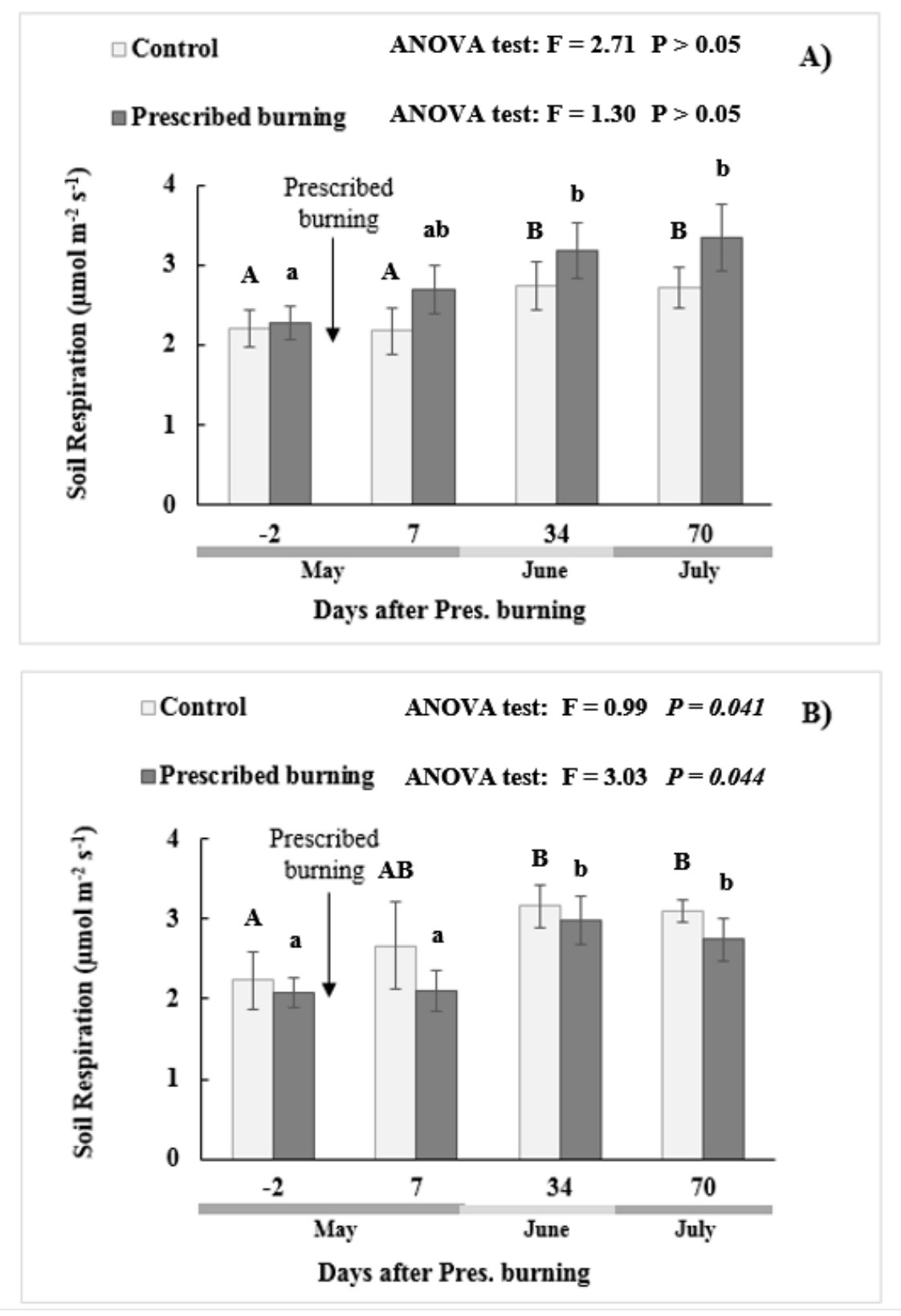

Figure 2. Temporal evolution of the soil respiration rates (mean $\pm \mathrm{SE}$ ) in the control and burned zones $\left(\mu \mathrm{mol} \mathrm{m}{ }^{-2} \mathrm{~s}^{-1}\right.$ ). (A) corresponds to the pure stand and (B) to the mixed stand. Bars with different capital letters represent the significant differences between the temporal times of the control treatment, while different lower-case letters show the differences between the temporal times in the burned plots. No differences were found between the burn treatment and the control within each time as there were no significant differences. 


\section{Discussion}

Soil temperature underwent significant differences between the control zone and the burned zone. In the pure stand, the burned zone presented a higher soil temperature due to greater exposure and absorption of radiation because of the elimination of shrubs and herbaceous vegetation. In the mixed stand, the control zone obtained significantly higher soil temperature values, which may be due to the exposure of the plots that are slightly south-facing. The temperature values correlated positively with SR, with higher respiration in the plots with a higher soil temperature, but with no significant differences in the respiration values. Regarding temporal evolution, soil temperature rose as summer air temperature and solar insolation increased.

Lack of changes in soil organic $\mathrm{C}$, total $\mathrm{N}$ and $\mathrm{C} / \mathrm{N}$ after prescribed burning seems to reflect low fire severity and is consistent with the findings of several authors [37-40]. No response of soil microbial $\mathrm{C}$ biomass is also consistent with low soil heating during prescribed burning, and with no changes in the soil chemical properties. Other authors have reported absence of changes or slight decreases up to 6 months after fire $[39,41]$ following fires in which the low temperatures on the soil surface during burning were measured.

Our results indicated high SR rates in summer, which is associated with higher soil surface temperature levels and microclimate aspects [42,43]. In addition, Austin and Vivanco [44], or Brandt et al. [45], have observed that an increase in UV radiation in soil favours litter decomposition, which may be due to microbial facilitation [46], and consequently increases SR [47]. Generally, no differences $(p>0.05)$ were found in the SR related to the prescribed burning treatment, because it was low-intensity burning compared to those reached in other studies, such as Granged et al. [48], where temperatures above $400{ }^{\circ} \mathrm{C}$ were reached for several minutes. Our results showed that prescribed fire did not influence SR since there was a similar evolution between the burned plots and the control plots after the prescribed fire in both the mixed and pure forest stands. However, it might be related to microclimatic conditions and the prescribed fires characteristics (see Section 3.1). Prescribed fires did not reach very high soil temperatures. Therefore, and due to the prescribed burn characteristics, we expected to find no differences when comparing the burned and control plots.

It is well-known that soil moisture is related to temperature, rainfall and evapotranspiration $[49,50]$. According to Baldrian et al. [51], soil moisture significantly affects the enzymatic activities and microbiological variables in forest soil. Many authors have demonstrated that low soil moisture generates low SR values as soil moisture is a major controlling factor for soil microbial activity [52].

In our study, the influence of lower soil moisture is weaker than a rise in soil temperature, therefore SR increases in the summer months. Fires have significant effects on not only soil quality, but also on the establishment and recovery of the vegetation community [53]. Other studies have observed recovery of microbial biomass, as indicated by increased SR [54]. Our results can be explained as soil microbiota and soil root systems were not affected by the low temperatures and residence time found during the prescribed fire.

Forest tree species influence soil function by changing soil temperature and moisture, which affect microbial activity and alter the dynamics and availability of soil nutrients [55,56]. Direct interactions exist between microbial and plant communities, and different plant inputs generate variations in the initial nutrient concentration and physico-chemical status of soil [57]. Our SR values were very similar when we compared the mixed and pure forest stands, which could be related to the studied pine species. Several research works have indicated differences in the microbial biomass and microbial community structure among stand types, but have always compared distinct tree genera. For example, Hannam et al. [58] found that Populus tremuloides forest floors supported greater microbial biomass than Picea glauca or mixed Populus remuloides and Picea glauca stand forest floors. More recently, Lucas-Borja et al. [59] demonstrated that mature and unmanaged Spanish black pine forest stands or mixed Spanish black pine with Holm oak (Quercus ilex) forests led to a higher accumulation of soil organic C compounds, which is directly connected with greater enzymatic activities, but not with 
greater microbial biomass. Finally, our results also showed that the soils found in the mixed or pure forest stands were strikingly similar in terms of soil characteristics and properties.

\section{Conclusions}

Prescribed fires were carried out on firebreak areas in pine forests of black pine with a low shrub fuel burden.

Our results suggest that the reduction of fuel under trees by low-intensity burnings does not affect the soil content in N, organic C and SR in the short term, which can be explained by the low temperatures reached during burning. These results correspond with those observed in other studies with similar characteristics. This silvicultural tool does not have negative effects on the studied variables under similar conditions. However, these results can be improved by extending the study with time. Thus it is advisable to address more study variables, such as an analysis of microorganisms in soil or enzymatic activity. SR is an important source of $C$ emissions to the atmosphere. Therefore, knowledge of it and its iterations with different fire uses can be key in sustainable forest ecosystem management. Thus, for prescribed burnings under trees, further studies are necessary to know the potential effects of this tool on soil biology.

Acknowledgments: We wish to thank the Regional Government of Castilla-La Mancha (Junta de Comunidades de Castilla-La Mancha) for carrying out the prescribed burnings, Javier Madrigal Olmo and Enrique Jiménez Carmona for providing the characterization data of the study area, and Helen Warburton for the reviewing the language. This study was supported by funds provided by the Castilla-La Mancha University to the Forest Ecology Research group. Finally, we thank the Spanish Institute for Agricultural and Food Research and Technology (INIA) for the funding awarded through National Research Projects GEPRIF (RTA2014-00011-C06).

Author Contributions: P.A.P.-Á., M.E.L.-B., D.M. and J.d.1.H. conceived and designed the experiment. P.A.P.-Á. and M.E.L.-B. performed statistical analysis tables and graphs. D.M. and J.S. contributed to the field work and writing of the manuscript. T.F. provided data and statistical analysis of soil properties and collaborated in the writing of the manuscript. M.E.L.-B. and P.A.P.-Á. wrote the manuscript and coordinated the reviews. All authors commented on the manuscript.

Conflicts of Interest: The authors declare no conflict of interest. The founding sponsors had no role in the design of the study; in the collection, analyses, or interpretation of data; in the writing of the manuscript, and in the decision to publish the results.

\section{References}

1. Pausas, J.G. Changes in fire and climate in the eastern Iberian Peninsula (Mediterranean basin). Clim. Chang. 2004, 63, 337-350. [CrossRef]

2. Moreno, J.M.; Oechel, W.C. The Role of Fire in Mediterranean Type Ecosystems; Springer: New York, NY, USA, $1994 ; 215 p$.

3. Piñol, J.; Terradas, J.; Lloret, F. Climate warming, wildfire hazard, and wildfire occurrence in coastal eastern Spain. Clim. Chang. 1998, 38, 345-357. [CrossRef]

4. Trigo, R.M.; Pereira, J.M.C.; Pereira, M.G.; Mota, B.; Calado, M.T.; DaCamara, C.C.; Santo, F.E. Atmospheric conditions associated with the exceptional fire season of 2003 in Portugal. Int. J. Clim. 2006, 26, 741-1757. [CrossRef]

5. Founda, D.; Giannakopoulos, C. The exceptionally hot summer of 2007 in Athens, Greece. A typical summer in the future climate? Glob. Planet. Chang. 2009, 67, 227-236. [CrossRef]

6. Cerdà, A.; Mataix-Solera, J. Efectos de los Incendios Forestales Sobre los Suelos en España; Publicacions de la Universitat de València: Valencia, Spain, 2009; 529p.

7. Fernandes, P.M. Empirical support for the use of prescribed burning as a fuel treatment. Curr. For. Rep. 2015, 1,118-127. [CrossRef]

8. Neary, D.G.; Klopatek, C.C.; DeBano, L.F.; Ffolliott, P.F. Fire effects on belowground sustainability: A review and synthesis. For. Ecol. Manag. 1999, 122, 51-71. [CrossRef]

9. Tolhurst, K.G.; Cheney, N.P. Synopsis of the Knowledge Used in Prescribed Burning in Victoria; Department of Natural Resources and Environment: East Melbourne, Australia, 1999; 97p. 
10. Ferreira, A.J.D.; Coelho, C.O.A.; Boulet, A.K.; Lopes, F.P. Temporal patterns of solute loss following wildfires in Central Portugal. Int. J. Wildland Fire 2005, 14, 401-412. [CrossRef]

11. Bird, R.B.; Bird, D.W.; Codding, B.F.; Parker, C.H.; Jones, J.H. The "fire stick farming" hypothesis: Australian Aboriginal foraging strategies, biodiversity, and anthropogenic fire mosaic. Proc. Natl. Acad. Sci. USA 2008, 105, 14796-14801. [CrossRef] [PubMed]

12. Cawson, J.G.; Sheridan, G.J.; Smith, H.G.; Lane, P.N.J. Surface runoff and erosion after prescribed burning and the effect of different fire regimes in forests and shrublands: A review. Int. J. Wildland Fire 2012, 27, 857-872. [CrossRef]

13. Morales, H.A.; Navar, J.; Dominguez, P.A. The effect of prescribed burning on surface runoff in a pine forest stand of Chihuahua, Mexico. For. Ecol Manag. 2000, 137, 199-207. [CrossRef]

14. Robichaud, P.R. Fire and erosion: Evaluating the effectiveness of a post-fire rehabilitation treatment, contour-felled logs. In Watershed Management and Operations Management; Asce: Reston, VA, USA, 2000; pp. 1-11.

15. Benavides-Solorio, J.D.; Macdonald, L.H. Measurement and prediction of post-fire erosion at the hillslope scale, Colorado Front Range. Int. J. Wildland Fire 2005, 14, 457-474. [CrossRef]

16. Robichaud, P.R.; Elliot, W.J.; Pierson, F.B.; Hall, D.E.; Moffet, C.A.; Ashmun, L.E. Erosion Risk Management Tool (ERMiT) User Manual Version 2006.01.18; General Technical Report RMRS-GTR- 188; US Department of Agriculture, Forest Service, Rocky Mountain Research Station: Fort Collins, CO, USA, 2007.

17. Raison, R.J.; Khanna, P.K.; Jacobsen, K.L.S.; Romanya, J.; Serrasolses, I. Effects of fire on forest nutrient cycles. In Fire Effects on Soils and Restoration Strategies; Cerdà, A., Robichaud, P.R., Eds.; Science Publishers: Enfield, NH, USA, 2009; pp. 225-256.

18. Úbeda, X.; Outeiro, L. Physical and chemical effects of fire on soil. In Fire Effects on Soils and Restoration Strategies; Cerdà, A., Robichaud, P.R., Eds.; Science Publishers: Enfield, NH, USA, 2009; pp. 105-132.

19. Mataix-Solera, J.; Guerrero, C.; García-Orenes, F.; Bárcenas, G.M.; Torres, M.P. Forest fire effects on soil microbiology. In Fire Effects on Soils and Restoration Strategies; Cerdà, A., Robichaud, P.R., Eds.; Science Publishers: Enfield, NH, USA, 2009; pp. 133-175.

20. Gutknecht, J.L.M.; Henry, H.A.; Balser, T.C. Inter-annual variation in soil extra-cellular enzyme activity in response to simulated global change and fire disturbance. Pedobiologia 2010, 53, 283-293. [CrossRef]

21. Hedo, J.; Lucas-Borja, M.E.; Wic, C.; Andrés-Abellán, M.; de Las Heras, J. Soil microbiological properties and enzymatic activities of long-term post-fire recovery in dry and semiarid Aleppo pine (Pinus halepensis M.) forest stands. Solid Earth 2015, 6, 243-252. [CrossRef]

22. Lucas-Borja, M.E.; Bastida, F.; Nicolás, C.; Moreno, J.L.; del Cerro, A.; Andrés, M. Influence of forest cover and herbaceous vegetation on the microbiological and biochemical properties of soil under Mediterranean humid climate. Eur. J. Soil Biol. 2010, 46, 273-279. [CrossRef]

23. Lucas-Borja, M.E.; Candel, D.; López-Serrano, F.R.; Andrés, M.; Bastida, F. Altitude-related 447 factors but not Pinus community exert a dominant role over chemical and microbiological 448 properties of a Mediterranean humid soil. Eur. J. Soil Sci. 2012, 63, 541-549. [CrossRef]

24. Lucas-Borja, M.E.; Candel, D.; Jindo, K.; Moreno, J.L.; Andrés, M.; Bastida, F. Soil microbial community structure and activity in monospecific and mixed forest stands, under Mediterranean humid conditions. Plant Soil 2012, 354, 359-370. [CrossRef]

25. Cerdà, A.; Flanagan, D.C.; le Bissonnais, Y.; Boardman, J. Soil erosion and agriculture Soil and Tillage. Research 2009, 106, 107-108.

26. Trasar-Cepeda, C.; Leirós, M.C.; Gil-Sotres, F. Hydrolytic enzyme activities in agricultural and forest soils. Some implications for their use as indicators of soil quality. Soil Biol. Biochem. 2008, 40, 2146-2155.

27. Raich, J.W.; Potter, C.S.; Bhagawati, D. Interannual variability in global soil respiration, 1980-94. Glob. Chang. Biol. 2002, 8, 800-812. [CrossRef]

28. Wei, W.; Weile, C.; Shaopeng, W. Forest soil respiration and its heterotrophic and autotrophic components: Global patterns and responses to temperature and precipitation. Soil Biol. Biochem. 2010, 42, 1236-1244. [CrossRef]

29. Marañón-Jiménez, S.; Castro, J.; Kowalski, A.S.; Serrano-Ortiz, P.; Reverter, B.R.; Sánchez-Cañete, E.P.; Zamora, R. Post-fire soil respiration in relation to burnt wood management in a Mediterranean mountain ecosystem. For. Ecol. Manag. 2011, 261, 1436-1447. [CrossRef] 
30. Smith, H.G.; Sheridan, G.J.; Lane, P.N.J.; Sherwin, C.B. Paired Eucalyptus forest catchment study of prescribed fire effects on suspended sediment and nutrient exports in south-eastern Australia. Int. J. Wildland Fire 2010, 19, 624-636. [CrossRef]

31. Muñoz-Rojas, M.; Lewandrowski, W.; Erickson, T.E.; Dixon, K.W.; Merritt, D.J. Soil respiration dynamics in fire affected semi-arid ecosystems: Effects of vegetation type and environmental factors. Sci. Total Environ. 2016, 572, 1385-1394. [CrossRef] [PubMed]

32. Harmon, M.E.; Bond-Lamberty, B.; Tang, J.; Vargas, R. Heterotrophic respiration in disturbed forests: A review with examples from North America. J. Geophys. Res. Biogeosci. 2011, 116. [CrossRef]

33. López-Serrano, F.R.; Rubio, E.; Dadi, T.; Moya, D.; Andrés-Abellán, M.; García-Morote, F.A.; Miettinen, H.; Martínez-García, E. Influences of recovery from wildfire and thinning on soil respiration of a Mediterranean mixed forest. Sci. Total Environ. 2016, 573, 1217-1231. [CrossRef] [PubMed]

34. Ditzler, C.; Scheffe, K.; Monger, H.C. Soil Survey Manual. Soil Science Division Staff; Agriculture Handbook No. 18; USDA, Government Printing Office: Washington, DC, USA, 2017.

35. Walkley, A.; Black, I.A. An examination of Degtjareff method for determining soil organic matter, and proposed modification of the chromic acid tritation method. Soil Sci. 1934, 37, 29-38. [CrossRef]

36. Vance, E.D.; Brookes, P.C.; Jenkinson, D.S. An extraction method for measuring soil microbial biomass C. Soil Biol. Biochem. 1987, 19, 703-707. [CrossRef]

37. Vega, J.; Landsberg, J.; Bará, S.; Paysen, T.; Fontúrbel, T.; Alonso, M. Efectos del fuego prescrito bajo arbolado de P. pinaster en suelos forestales de Galicia y Andalucía. Cuad. Soc. Esp. Cienc. For. 2000, 9, 123-136.

38. Granged, A.J.P.; Zavala, L.M.; Jordán, A.; Bárcenas-Moreno, G. Post-fire evolution of soil properties and vegetation cover in a Mediterranean heathland after experimental burning: A 3-year study. Geoderma 2011, 164, 85-94. [CrossRef]

39. Fontúrbel, M.T.; Barreiro, A.; Vega, J.A.; Martín, A.; Jiménez, E.; Carballas, T.; Fernández, C.; Díaz-Raviña, M. Effects of an experimental fire and post-fire stabilisation treatments on soil microbial communities. Geoderma 2012, 191, 51-60. [CrossRef]

40. Fontúrbel, M.T.; Fernández, C.; Vega, J.A. Prescribed burning versus mechanical treatments as shrubland management options in NW Spain: Mid-term soil microbial response. Appl. Soil Ecol. 2016, 107, 334-346. [CrossRef]

41. Catalanotti, A.E. Effects of Prescribed Burning on Soil and Vegetation. Ph.D. Thesis, Universidad de Nápoles, Federico II, Naples, Italy, 2011. Available online: http:/ / www.fedoa.unina.it/8771/1/Catalanotti_Ambra_ Elena_24.pdf (accessed on 27 March 2017).

42. Moya, D.; Heras, J.; López-Serrano, F.R.; Ferrandis, P. Post-Fire Seedling Recruitment and Morpho-Ecophysiological Responses to Induced Drought and Salvage Logging in Pinus halepensis Mill. Stands. Forests 2015, 6, 1858-1877. [CrossRef]

43. Curiel-Yuste, J.C.; Janssens, I.A.; Carrara, A.; Ceulemans, R. Annual $Q_{10}$ of soil respiration reflects plant phenological patterns as well as temperature sensitivity. Glob. Chang. Biol. 2004, 10, 161-169. [CrossRef]

44. Austin, A.T.; Vivanco, L. Plant litter decomposition in a semiarid ecosystem controlled by photodegradation. Nature 2006, 442, 555-558. [CrossRef] [PubMed]

45. Brandt, L.A.; Bohnet, C.; King, J.Y. Photochemically induced carbon dioxide production as a mechanism for carbon loss from plant litter in arid ecosystems. J. Geophys. Res. Biogeosci. 2009, 114. [CrossRef]

46. Caldwell, M.M.; Bornman, J.F.; Ballaré, C.L.; Flint, S.D.; Kulandaivelu, G. Terrestrial ecosystems, increased solar ultraviolet radiation, and interactions with other climate change factors. Photochem. Photobiol. Sci. 2007, 6, 252-266. [CrossRef] [PubMed]

47. Rey, A.; Pegoraro, E.; Oyonarte, C.; Were, A.; Escribano, P.; Raimundo, J. Impact of land degradation on soil respiration in a steppe (Stipa tenacissima L.) semi-arid ecosystem in the SE of Spain. Soil Biol. Biochem. 2011, 43, 393-403. [CrossRef]

48. Granged, A.J.P.; Jordán, A.; Zavala, L.M.; Muñoz-Rojas, M.; Mataix-Solera, J. Short-term effects of experimental fire for a soil under eucalyptus forest (SE Australia). Geoderma 2011, 167-168, 125-134. [CrossRef]

49. Wang, Q.; Zhong, M.; Wang, S. A meta-analysis on the response of microbial biomass, dissolved organic matter, respiration, and $\mathrm{N}$ mineralization in mineral soil to fire in forest ecosystems. For. Ecol. Manag. 2012, 271, 91-97. [CrossRef] 
50. Xu, W.; Gu, S.; Zhao, X.; Xiao, J.; Tang, Y.; Fang, J.; Jiang, S. High positive correlation between soil temperature and NDVI from 1982 to 2006 in alpine meadow of the Three-River Source Region on the Qinghai-Tibetan Plateau. Int. J. Appl. Earth Obs. Geoinform. 2011, 13, 528-535. [CrossRef]

51. Baldrian, P.; Merhautova, V.; Cajthaml, T.; Petrankova, M.; Snajdr, J. Small-scale distribution of extracellular enzymes, fungal, and bacterial biomass in Quercus petraea forest topsoil. Biol. Fertil. Soils 2010, 46, 717-726. [CrossRef]

52. Merilä, P.; Strömmer, R.; Fritze, H. Soil microbial activity and community structure along a primary succession transect on the land-uplift coast in western Finland. Soil Biol. Biochem. 2002, 34, 1647-1654. [CrossRef]

53. Certini, G. Effects of fire on properties of forest soils: A review. Oecologia 2005, 143, 1-10. [CrossRef] [PubMed]

54. Fritze, H.; Pennanen, T.; Pietikäinen, J. Recovery of soil microbial biomass and activity from prescribed burning. Can. J. Res. 1993, 23, 1286-1290. [CrossRef]

55. Moukoumi, J.; Munier-Lamy, C.; Berthelin, J.; Ranger, J. Effect of tree species substitution on organic matter biodegradability and mineral nutrient availability in a temperate topsoil. Ann. For. Sci. 2006, 63, 763-771. [CrossRef]

56. Weand, M.P.; Arthur, M.A.; Lovett, G.M.; McCulley, R.L.; Weathers, K.C. Effects of tree species and N additions on forest floor microbial communities and extracellular enzyme activities. Soil. Biol. Biochem. 2010, 42, 2161-2173. [CrossRef]

57. Thoms, C.; Gattinger, A.; Jacob, M.; Thomas, F.M.; Gleixner, G. Direct and indirect effects of tree diversity drive soil microbial diversity in temperate deciduous forest. Soil Biol. Biochem. 2010, 42, 1558-1565. [CrossRef]

58. Hannam, K.D.; Quideau, S.A.; Kishchuk, B.E. Forest floor microbial communities in relation to stand composition and timber harvesting in northern Alberta. Soil Biol. Biochem. 2006, 38, 2565-2575. [CrossRef]

59. Lucas-Borja, M.E.; Bastida, F.; Moreno, J.L.; Nicolás, C.; Andres, M.; Lopez, F.R.; Del Cerro, A. The effects of human trampling on the microbiological properties of soil and vegetation in Mediterranean mountain areas. Land Degrad. Dev. 2011, 22, 383-394. [CrossRef]

(C) 2017 by the authors. Licensee MDPI, Basel, Switzerland. This article is an open access article distributed under the terms and conditions of the Creative Commons Attribution (CC BY) license (http:/ / creativecommons.org/licenses/by/4.0/). 